\title{
An Influence of Parental Habits and Behavior in Children's Education
}

\author{
Salma Rozana ${ }^{1}$, Munisa $^{2}$, Rita Nofianti $^{3}$, Rika Widya $^{4}$ \\ ${ }^{1,2,3,4}$ Lecturer Of Faculty Islam and Humanity, Universitas Pembangunan Panca Budi Medan, North Sumatera, \\ Indonesia
}

Corresponding Author: Salma Rozana

\begin{abstract}
This research discussed the responsibilities of parents in education early childhood. From the literature review, it is known that the family environment is the main place for a child to get an education. Fathers and mothers in the family become the first educators in the process of developing children's lives. Parents do not just build relationships and carry out various family goals for reproduction, continuing offspring, and establishing affection. The main task of the family is to create a building and atmosphere for the family education process so that it gives birth to a generation of intelligent and noble character as a solid footing in the life and journey of a human child. This fact is supported by the findings of theories that support the importance of family education as the first basis for children's education.
\end{abstract}

Keywords: family, education, early childhood.

\section{INTRODUCTION}

The family is an educational institution first and foremost. Families are always expected to try to provide the needs, both biological and psychological, for children and care for and educate them. Families are expected to produce children who can grow into individuals and can live during society. At the same time, they can accept and inherit the values of life and culture.

According to Selo Soemarjan, the family is the core group because the family is the first educational community and is natural. In the family, children are prepared to undergo stages of development as a provision when entering the world of adults, language, customs, and all cultural contents, should be a task carried out by families and communities in maintaining life by the family.

In the family vehicle, parents, especially fathers as the head of the family with the help of their members, must prepare everything that a family needs- such as guidance, invitations, giving examples, sometimes sanctions that are typical in a family, whether in the form of household, religious or other social work, which all family members bear, or individually, including interactions in family education. According to $\mathrm{Ki}$ Hajar Dewantara, the family is a collection of individuals who have a sense of selfless devotion for the benefit of all individuals who take shelter in it. So important is the family of human life for individuals and groups of people

Children can not be separated from the family; family people can gather, meet and stay in touch. It can be imagined if humans live without family. Without realizing it, indirectly, it has eliminated the nature of a person as a social being. This aligns with Selo Soemarjan's statement; a family is a group of people united by kinship ties, marriage, or approved adoption. Socially and generally by welldefined social roles, Abdullah and Berns also reinforce the argument that a family is a social group characterized by a place to live together, economic cooperation, and reproduction. On the other hand, in the 
context of psychological understanding, the family is defined as a collection of people who live together with a commonplace to live. Each person involved feels an inner connection so that mutual attention, mutual assistance, socialization, and surrender occur.

Likewise, in terms of pedagogical views. The family is a living fellowship woven by the love between the couple of two human beings confirmed by marriage to perfect each other.

In addition, the family is a place to educate children to be smart, experienced, knowledgeable, and well-behaved. Both parents must understand well the obligations and responsibilities as parents. Parents (father and mother) do not just build relationships and carry out various family goals, such as reproduction, continuing offspring, establishing affection, etc.

The task of the family is very urgent, namely to create an atmosphere in the family of a continuous process of education (continues progress) to give birth to the next generation (descendants) who are intelligent and have good character (good character)both in the eyes of parents and society.

Strong foundations and foundations are the beginning of education in the family, a solid foundation in treading a tougher life, and broad for the next journey of human children.

In various literatures, experts provide various points of view on the meaning of family education. For example, Mansur defines family education as providing positive values for the growth and development of children as the foundation for further education. In addition, Abdullah also defines family education as all efforts made by parents in habituation and improvisation to help children's personal development. 9 Another opinion expressed by an-Nahlawi, Hasan Langgulung, limits the understanding of family education as an effort made by fathers and mothers as people who are given the responsibility to provide values, morals, exemplary and fitrah.

\section{LITERATURE REVIEW}

Ki Hajar Dewantara, one of the leaders of Indonesian education, also stated that the family realm for everyone (children) is the realm of initial education. For the first time, parents (father and mother) serve as guides (teachers), as teachers, as educators, mentors, and primary educators for children. So it is not excessive when referring to the opinions of experts on the concept of family education. Not just an action (process), but it is present in practice and implementation, which is carried out by parents (fathermother) with educational values in the family.

Please note, the majority of parents do not know how the concept of family education is. This cased is without realizing the parents (father and mother) in their daily practice. They have performed family functions in the education of children. In essence, the function of the family is as education of character, social, citizenship, habit formation, and intellectual education of children.

1. Mollehnhaur in Abdullah divides the family into three functions in the education of children, namely:

2. The quantitative function, which provides for the formation of basic behavior, means that the family not only provides the basic physical needs of the child, in the form of clothing, food, and drink, and a decent place to live. However, the family must provide and facilitate the availability of the basics of goodness, in the form of behavior, ethics, manners, and the formation of a child's character who is polite and has good character as an essential human nature.

3. Selective functions, namely filtering children's experiences and unequal social positions due to the learning environment. This method means that family education functions and plays the role of controlling the child's selfcontrol for various information received by the child.12 especially children aged 00 to 05 years who do not have the 
knowledge and experience. So that it is expected to be able to distinguish between good and bad, therefore, the family (father and mother) is obliged to provide meaningful information and experiences. In direct or indirect learning experiences, it is hoped that these experiences can be absorbed and transformed in children.

4. The pedagogical function is to pass on values and norms. This method means that family education functions to provide a legacy of values related to aspects of the child's personality. The final project of family education is reflected in attitudes, behavior, and personality.

Personality of children in everyday life that are displayed.

Meanwhile, it turns out that the function of the family is not limited to that; for example, Berns13, put forward the function of the family, namely:

(a) reproductive function,

(b) carrying out education and socialization in society,

(c) building social rules,

(d) take economic action, and

(e) build and support the process of children's emotional development.

\section{a. Theories of Family Education in Early Childhood JH Pestalozzi (1746 - 1827).}

Another educational figure who has also laid the foundation for early childhood education is Johan Hendrik Pestalozzi. He was born in Zurich, Switzerland, in 1746. In 1774 he started by establishing the first school called "Neuhof" on his farm. There he developed his ideas in the world of education, where the most focused idea was integrating education in domestic life, vocational education, and reading and writing education.

Pestalozzi is of the view that education should follow the child's nature. This education uses the method, which combines the natural world, especially the family realm, and practical education. The way is to guide the child slowly. It can be done by starting a child's own business, giving children the opportunity to act and do something that starts from "senseimpression" to abstract ideas.

Pestalozzi believes that all forms of education are based on the influence of the five senses and, through experience and potential, to be developed. The household environment is considered the center of activity for mothers in educating children; mothers have the greatest responsibility in children's education. So Pestalozzi thought that others are heroes in the education of their children.

\section{b. Mothers are people who encourage their children to learn from the very beginning of a child's life Friedrich Frobel (1782 - 1852).}

$\mathrm{He}$ was born in the city of Oberweisbach, Germany, in 1782. Frobel learned a lot about the concept of education from his predecessor, JH Pestalozzi, who he considers as the "father" of children's education and learning. In 1817 Frobel founded a college in the City of Keilhau (Germany) using the system of Pestalozzi. Especially for children's education, Frobel founded "Kindergarten" (kindergarten). That was the first Frobel school that was founded in the city of Blanckenburg, Germany. Besides founded a kindergarten (Kindergarten), also founded a "mother's garden" (Frobel Kweekschool).

Frobel initiated children's education, including playing, singing, and various kinds of children's work, to direct experience. For Frobel, if children do not move and are more silent, it is a sign that the child is not healthy in body or soul. The movement of children is the result of the movement of their souls because the soul and body of children are one. Body movements will affect children's souls to grow and develop.

Frobel's educational concept also inspired him to create various forms of games so that he is expected to give birth to healthy children, both physically and spiritually. The games initiated by Frobel's 
School can be played if the following conditions are taken into account:

a. Games should please children,

b. Games should provide opportunities for children to fantasize,

c. Children must be capable and able to complete the game,

d. Give game work that also contains art, and The game is expected to contain and direct children towards order. Frobel intends this order to educate children "a sense of decency", and in the future, it is hoped that children will have social and humanitarian attitudes.

\section{c. Maria Montessori (1870-1952)}

He was born in Italy (Rome) in 1870. She was a female doctor and stopped her medical practice in 1900 . Then she plunged into the world of education by studying children's psychology (Kinder Psychologie).

In 1907 Maria Montessori received an offer from a Roman businessman to establish a school for children. By the wealthy businessman, Montessori was given the authority to manage the school properly. The offer was accepted, and Maria Montessori finally founded "Casa Dei Bambini," which means "a house to care for children". Montessori views early childhood development as a continuous process. Education is self-activity and directs children to the formation of personal discipline, independence, and self-direction.

\section{MATERIALS \& METHODS}

To meet the educational needs of these children, he designed several materials that allow children's senses to develop properly and perfectly. When a child learns about sound (through hearing), Montessori designs a set of boxes. All the boxes are the same, but each box contains a different material, so it will make a different sound when shaken. Furthermore, Montessori designed learning tools to improve the functions of sight, smell, taste, and touch in a very distinctive way and the principle of self-evaluation.
No less interesting than the concept of Montessori education theory is physical education, which develops muscles, gardens and learns about nature. With education about nature, gardening and Developing muscles through exercise, it is hoped that children will have life experiences and have a healthy and strong physique. Thus, children will be able to learn with various kinds of knowledge. He believes that at an early age of $02-06$ years is a period that is considered very "sensitive" to learn to read and count.

\section{Abu Hamid Muhammad Al-Gazali (1058 M - 1111 AD)}

Al-Gazali was born in the city of Tos Khurasan (Persia). Since childhood, alGazali was fond of science; he has extraordinary intelligence. To the extent that Imam Al-Juwaini dubbed the "Bah\}r Mugriq" (the drowning ocean). Another advantage of al-Gazali is his ability to engage in debate (dialogue) with some thinkers, scholars, and people considered to have superior knowledge from him. His ability to debate this has led him to be asked by the ruler (king) at that time to assist in educating and teaching religious knowledge to the children of the King and his soldiers in the city of Baghdad (now Iraq); this happened in $484 \mathrm{H} / 1091 \mathrm{AD}$.

Imam al-Gazali's breadth and wisdom in managing life in this world has also delivered it to the Sufi way of life. This is marked by his teachings which later become references and references for people who want to explore the nature through the teachings of Sufism. The book that was first compiled to find out about his life, he arranged in "al- Munqidz min al-Da\} lal". In this book contains and contains a picture of life, especially when there is a change in his view of life and values. al-Gazali describes the process of internalizing Faith in the soul, how the divine essences can be revealed to humans. How can humans achieve ma'rifat with full confidence without going through processes and logic, but by way of inspiration and Sufi tracking 
Al-Gazali, in the concept of education, said that religious education should start from an early age. Because, in this situation, the child is ready to accept religious aqidah solely based on faith, without asking for evidence to strengthen it or demanding certainty and explanation. Therefore, in teaching religion to children, one should start by memorizing the rules and basics. After that, the teacher explains the meaning so that they understand, believe, and justify it.

According to al-Gazali, early childhood should be introduced to religion because humans are born to have brought religion as the religion brought by their parents (father-mother). Therefore a child will follow the religion of both parents and teachers. This concept makes both parents as educators who are the main strengths in children. Children grow and develop towards the purification of the soul, noble character, piety and are expected to spread virtue to all humanity.

Al-Gazali's thoughts on the concept of education, he poured in his famous book, namely "Ih $\}$ ya" "Ulu>m al-Di>n". Today's essay has become a reference and foundation for some Muslim thinkers who raise educational issues, especially family education.

\section{Ki Hajar Dewantara (1889 - 1959)}

One of the influential figures in the world of education in Indonesia is Ki Hajar Dewantara. He was born in the Kauman area, Yogyakarta, onMay 2, 1889, and died on April 26, 1959. In this City of Education, Ki Hajar Dewantara inspired the birth of the Taman Siswa National College in Yogyakarta on July 3, 1922. The first year After its establishment, Taman Siswa opened a school named "Taman Lare" or "Children's Park".

There were also junior high schools and junior high schools at the Taman Siswa National College in further developments. For conformity with the mental characteristics of children according to their age, each level of education is given a name.
"Children's Park" for class I to class III for children aged 7-9 years. "Taman Muda" for young children for children in grades IV to VI aged between 10-13 years. Then for grade VII and junior high school for adult children, it is named "Adult Park".

Ki Hajar Dewantara's concept of education he poured through the "Tri Sentra Pendidikan" developed at the Taman Siswa College, namely family centers, college centers, and community centers. In the context of family centers, family education has given birth to the concept of "among", where this concept requires parents to behave, namely: (a) ing also sung toledo, (b) ing Madya man gun kasra, (c) tut wuri handayani.

In the context of a family center, $\mathrm{Ki}$ Hajar Dewantara cares about paying attention, even asking parents to educate their children from an early age (family realm). The family realm is the best place for moral and social education. So it can be said that a family is a place of education that is more perfect in nature and form than other places to carry out education towards character intelligence (the formation of individual character) and as a provision for social life.

The importance of family education for the growth and development of children Ki Hajar Dewantara (1961) further stated that the family realm is, In the early education realm, education for the first time in education from parents who position as a teacher (prosecutor), as a teacher, and as a leader,

\section{In the family, the children are educated,}

a. In the family children have the opportunity to educate themselves, because in family life they are not different in position,

b. In the family, parents act as teachers and guides, as teachers, as role models and role models.

\section{You are Muhammad Syafe'i}

Tengku Muhammad Syafe'i was born in West Kalimantan, to be exact in the 
Nathan area, in 1895, and he was of Mining blood. Son of Mara Sutan and Indung Khodijah. After Ki Hajar Dewantara founded the Taman Siswa National College in Yogyakarta. In the Sumatra region, an intelligent and progressive thinker emerged from the educated people of Sumatra, especially West Sumatra. With the educational background taken while in Java and supported by a family background that understands the importance of education and struggle, then in the hands of Muhammad Syafe'i in 1926, the Indonesisch Nederlandsche School (INS) Kayu Tanam was born, precisely on October 31, 1926.

The presence of INS Kayu Tanam in Sumatra as an educational institution has given birth to new hope among the indigenous people. By its ideals, the school functions to hone the intelligence and reason of students, not to form other human beings from themselves. The educational goal of INS Kayu Tanam is to produce human beings who are creative, innovative, intellectual, noble, independent, intelligent, and have a work ethic. Furthermore, Tengku Muhammad Syafe'i in Anfasa Moelok19 stated that:

"Educating and fostering students should always be creative in developing their talents and knowledge, independent, intelligent and with a work ethic, capable of Intellectual, insightful and cultured, faithful, pious, and noble in their service to the community.

\section{ANALYZE AND RESULTS}

National education system law number 20 of 2003, Chapter I Article 1, paragraph 13, states that "informal education is the path of family and environmental education." Furthermore, Article 27, paragraph 1 emphasizes that "informal educational activities carried out by families and the environments are in the form of independent learning activities". Based on the law above, constitutionally, an informal educational path (education within the family) becomes a formal legal force. In terms of citizenship rights, it should be implemented by all.

Parents. Moreover, the technical provisions for operationalization have formal juridical provisions.

In practice, family education has not been fully implemented by parents who have children at home. There are many factors why then the concept of education in the family that parents should have given has not been optimally practiced in parents' daily lives in educating their children at home. According to the author's thoughts, the factors causing the problem are:

a. Lack of knowledge and understanding of parents about the position of parents' roles and responsibilities and responsibilities in terms of educating children at home. Lack of knowledge and understanding can be caused by parents' low level of education due to the inability to complete school. We can see this in the number of children dropping out of school, the increasing number of uneducated unemployed, and the weak competition in the workforce.

b. Weak socio-cultural role of society in building awareness of the importance of family education. Families often ignore educational values in the household realm by allowing children to play and socialize without control, lack of attention when communicating with each other- the apathetic attitude of most parents to the manners of children's association in the play environment.

c. The strong pressure and pull of the economic struggle of parents in meeting the demands and needs of the family. So that they ignore the roles as functions and duties of parents even without realizing it, due to the demands of their economic needs (father and mother) forget their responsibilities as parents. They leave children without proper care, guidance and education. In many cases, watching many children grow up without parental attention in front of our own eyes. Even by taking a deep breath, we see that children have been used as 
tools (objects) of commercialization for parents to earn income (money) to meet family needs.

d. The progress of the widespread flow of information technology also affects the way parents think and act. For example, instant behavior by providing media facilities that are not educational, allowing access to various information that is not educational, either through television media shows and uncontrolled supervision (protection), due to the ignorance of parents.

It must be acknowledged that the confusion of the stakeholders in this country witnessing many children do not get great attention from parents. Finally, the Government, through the competent institutions and institutions, has launched the "Early Childhood Education" movement, which is contained in the National Education System Law (Sisdiknas) in the seventh part of article 27 paragraph 5, which states "Early Childhood Education on the informal channel". in the form of family education or education organized by the environment. Paragraph 1 reads, "Early Childhood Education is held before the basic education level".

The fact above confirms to us, parents, that children's education should be given from the beginning by parents. If possible, the education of these children can be given when a mother is pregnant with the baby once the urgency of family education has signaled to parents to be serious in making family education a strong foundation. Educating children is very useful to develop their potential so that the child becomes a person with intelligent, perfect, and superior personality in knitting a child's future that is coveted by all parents, society, and the country.

\section{CONCLUSION}

The family is the main and first institution for the initial process of children's education to develop a child's potential towards the development of a positive and good personality. Parents (father and mother) have a great responsibility in educating children in the family. The functions and roles of parents are not only to meet the physical needs of children in the form of food and drink, clothing, shelter but also the responsibility of distant parents.

More important than that is to give attention, guidance, direction, motivation, education, and the cultivation of values. The magnitude of the responsibility of parents (father and mother) to educate children in a family environment is also supported by educational theories put forward by philosophers and thinkers who devote their lives to the world of education. Such as Comenius, JH Pestolozzi, F. Frobel, Maria Montessori, Al-Gazali, Ki Hajar Dewantara and Engku Muhammad Syafe'i. The concepts offered through these theories have become references and references for the development and development of children's education, especially Early Childhood Education (PAUD) in Indonesia.

\section{Acknowledgement: None}

\section{Conflict of Interest: None}

\section{Source of Funding: None}

\section{REFERENCES}

1. Abdullah, M. Imron, Family Education for Children, (Cirebon: Lektur, 2003).

2. Soenarjo, A., Al-Qur'an and its translation, (Jakarta: Teraju, 1989). Berns, Roberta M., children, Family, School, Community Socialization and support, (United States: Thomson Corporation, 2007).

3. Hasan, Fathiyah Sulaiman, Al-Gazali's Mind Regarding Education and Science, (Bandung: Diponegoro, 1986).

4. Jalal, Fasli \& Farid Anfasa Moeloek, ISN Timber Planting Seminar Materials, (2006).

5. Dewantara, Ki Hajar, Educational Sciences, (Yogyakarta: Taman Siswa, 1961).

6. Langgulung, Hasan, Humans and Education, (Jakarta: Pustaka al-Husna, 1986). 
7. Mansur, Early Childhood Education in Islam, (Yogyakarta: Pustaka Pelajar, 2005).

8. Patmonodewo, Soemiarti, Preschool Education, (Jakarta: Rineka Cipta, 2003).

9. Sadullah, Uyoh, Introduction to the Philosophy of Education, (Bandung: Alfabeta, 2007).
10. Soemarjan, Selo, Sociology An Introduction, (Yogyakarta: Gajah Mada Press, 1962).

How to cite this article: Rozana S, Munisa, Nofianti $R$ et.al. An influence of parental habits and behavior in children's education. International Journal of Research and Review. 2021; 8(8): 306-313. DOI: https:// doi.org/10.52403/ijrr.20210842 